WSRC-TR-2003-00124, Rev. 1

Keywords

Benzene

Tetraphenylborate

\title{
Tank 50H Flammability Calculations
}

D. P. Lambert

J. T. Mills

March 20, 2003

\section{Westinghouse}

Savannah River Company

Aiken, SC 29808

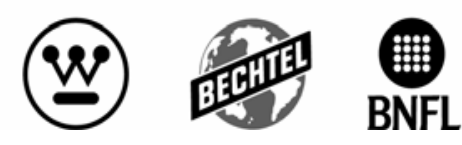


This document was prepared in conjunction with work accomplished under Contract No. DE-AC09-96SR18500 with the U. S. Department of Energy.

\section{DISCLAIMER}

This report was prepared as an account of work sponsored by an agency of the United States Government. Neither the United States Government nor any agency thereof, nor any of their employees, makes any warranty, express or implied, or assumes any legal liability or responsibility for the accuracy, completeness, or usefulness of any information, apparatus, product or process disclosed, or represents that its use would not infringe privately owned rights. Reference herein to any specific commercial product, process or service by trade name, trademark, manufacturer, or otherwise does not necessarily constitute or imply its endorsement, recommendation, or favoring by the United States Government or any agency thereof. The views and opinions of authors expressed herein do not necessarily state or reflect those of the United States Government or any agency thereof.

This report has been reproduced directly from the best available copy.

Available for sale to the public, in paper, from: U.S. Department of Commerce, National Technical Information Service, 5285 Port Royal Road, Springfield, VA 22161, phone: (800) 553-6847, fax: (703) 605-6900

email: orders@ntis.fedworld.gov

online ordering: http://www.ntis.gov/help/index.asp

Available electronically at http://www.osti.gov/bridge

Available for a processing fee to U.S. Department of Energy and its contractors, in paper, from: U.S. Department of Energy, Office of Scientific and Technical Information, P.O. Box 62, Oak Ridge, TN 37831-0062,

phone: (865)576-8401,

fax: (865)576-5728

email: $\underline{\text { reports@ adonis.osti.gov }}$ 
Page 3 of 20

\section{Table of Contents}

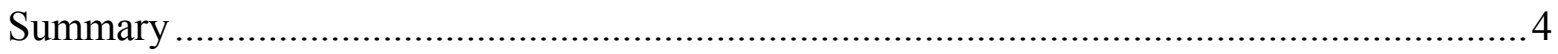

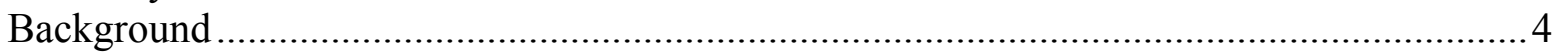

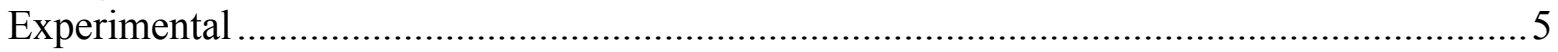

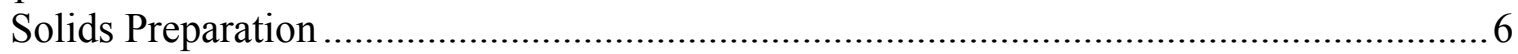

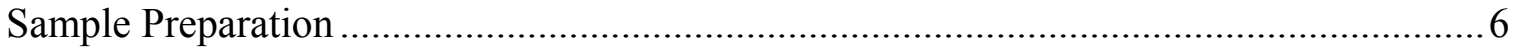

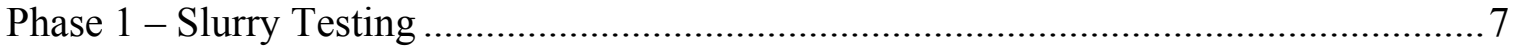

Phase 2 - Solids Left Behind Testing ..................................................................... 8

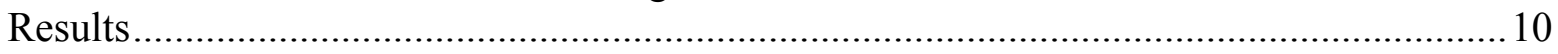

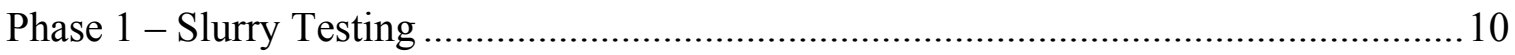

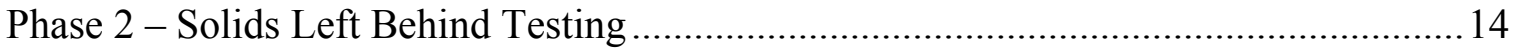

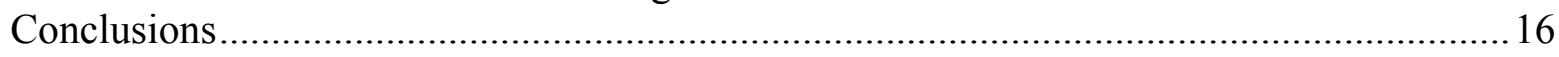

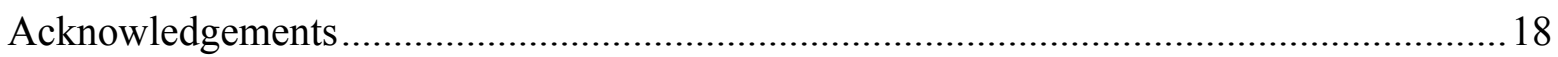

\section{List of Figures}

Figure 1 - Photograph of Tank 50H solids plus Inhibited Water ..................................... 8

Figure 2 - 4PB Degradation Rate Comparison of IW versus Tank 23H supernate ..............11

Figure 3 - Phenol and 4PB concentration profiles for IW plus Tank $50 \mathrm{H}$ solids at $50{ }^{\circ} \mathrm{C} \ldots 12$

Figure 4 - Comparison of Decomposition Rate at Low versus High Tank Volume............. 14

Figure 5-4PB decomposition in solids left behind after slurrying ................................. 16

\section{List of Tables}

Table 1 - Predicted 4PB Decomposition Rate, mol/day...................................................5

Table 2 - 4PB analysis of 1.8 gram sub-samples, $\mathrm{mg} / \mathrm{kg}$ solids.................................... 6

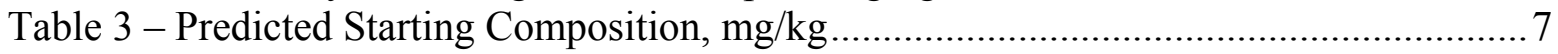

Table 4 -- Phase 1 Experiment Summary Table …...................................................... 7

Table 5 - Phase 2 Experiments Summary Table ….................................................... 8

Table 6 - Recipe for High Hydroxide and High Nitrate Simulants.................................... 9

Table 7 - Enhanced Catalyst Composition................................................................... 10

Table 8 - Data Comparison for Week \#3 Testing comparing IW and Tank $23 \mathrm{H}$ at $50{ }^{\circ} \mathrm{C} \ldots 11$

Table 9 - Comparison of decomposition rate of 300,000 gal versus $1,000,000$ gal............. 14 


\section{Summary}

This report summarizes the results of testing to determine the 4PB degradation rate of solids in Tank $50 \mathrm{H}$. Phase 1 was designed to determine the tetraphenylborate (4PB) decomposition rate of the $4 \mathrm{~PB}$ present in Tank $50 \mathrm{H}$ if Tank $23 \mathrm{H}$ or Inhibited Water (IW, water with added sodium nitrite and sodium hydroxide to inhibit corrosion of the carbon steel waste tanks) is added to the tank. The following preliminary results, at $95 \%$ confidence limits, are presented:

$>$ The $4 \mathrm{~PB}$ decomposition rate at $50{ }^{\circ} \mathrm{C}$ is $-2.23 \mathrm{E}-06 \pm 1.33 \mathrm{E}-06 \mathrm{~mol} / \mathrm{L} /$ day for Tank $23 \mathrm{H}$ and $-1.74 \mathrm{E}-06 \pm 0.35 \mathrm{E}-06 \mathrm{~mol} / \mathrm{L} /$ day for IW at $50{ }^{\circ} \mathrm{C}$, assuming a linear regression analysis based on the calculated initial $4 \mathrm{~PB}$ concentrations.

$>$ The maximum benzene generation rate from 4PB decomposition is $8.90 \mathrm{E}-06 \pm 5.30 \mathrm{E}-06$ $\mathrm{mol} / \mathrm{L} /$ day for Tank $23 \mathrm{H}$ and $6.95 \mathrm{E}-06 \pm 1.41 \mathrm{E}-06 \mathrm{~mol} / \mathrm{L} /$ day for $\mathrm{IW}$ at $50{ }^{\circ} \mathrm{C}$. This assumes all of the $4 \mathrm{~PB}$ degrades to benzene.

$>$ Based on our testing, approximately $90 \%$ of the $4 \mathrm{~PB}$ primarily decomposes to phenol, not benzene. The likely benzene generation rate from $4 \mathrm{~PB}$ decomposition is roughly $8.90 \mathrm{E}-07 \pm 5.30 \mathrm{E}-07 \mathrm{~mol} / \mathrm{L} /$ day for Tank $23 \mathrm{H}$ and $6.95 \mathrm{E}-07 \pm 1.41 \mathrm{E}-07 \mathrm{~mol} / \mathrm{L} /$ day for IW at $50{ }^{\circ} \mathrm{C}$.

$>$ Because of the limited data available and questions concerning the uniformity of the solids, the $95 \%$ confidence limit that gives the most conservative estimate of the $4 \mathrm{~PB}$ decomposition rate.

$>$ No testing at $100{ }^{\circ} \mathrm{C}$ was performed because of the fast decomposition at $50{ }^{\circ} \mathrm{C}$.

Phase 2 was designed to determine the $4 \mathrm{~PB}$ decomposition rate if a high hydroxide or high nitrate salt solution is added to the tank. Any $4 \mathrm{~PB}$ solids left behind after the slurry operation are expected to decompose more slowly based on the fact that future solutions are expected to have high free hydroxide concentrations and the tank will be at temperatures closer to ambient than $50{ }^{\circ} \mathrm{C}$.

$>$ The $4 \mathrm{~PB}$ decomposition rate at $50{ }^{\circ} \mathrm{C}$ is $-4.14 \mathrm{E}-07 \pm 5.72 \mathrm{E}-07 \mathrm{~mol} / \mathrm{L} /$ day for High Hydroxide simulants at $50^{\circ} \mathrm{C}$, assuming a linear regression analysis based on the calculated initial $4 \mathrm{~PB}$ concentrations.

The 4PB decomposition is expected to produce primarily phenol, not benzene, during the planned slurrying and feeding of the slurry to Saltstone. Pulling a Tank $50 \mathrm{H}$ slurry sample towards the end of feeding to Saltstone is recommended. The 4PB analysis of this sample could be used to better estimate the $4 \mathrm{~PB}$ potential in Tank $50 \mathrm{H}$ than a solids estimate combined with analyses of Tank $50 \mathrm{H}$ solids after Tank $50 \mathrm{H}$ is emptied. This data could be used to formulate a better flammability strategy for Tank $50 \mathrm{H}$.

\section{$\underline{\text { Background }}$}

Decontaminated liquid waste at the Savannah River Site is grouted for disposal in the Saltstone Facility. Tank $50 \mathrm{H}$ serves as a staging tank and routinely transfers supernate to 
Page 5 of 20

the Saltstone feed tank. During October of 2002, the mass balances for transfers from Tank $50 \mathrm{H}$ to Saltstone started to show discrepancies. On October 22, 2002, the differences in mass balance between the two facilities exceeded a preset value of $10 \%$.

At that time, High Level Waste Operations personnel inserted a video camera into the riser nearest the discharge point to Saltstone and observed a mound of solids. Subsequent to that observation, an inspection in the opposite (northeast) quadrant of the tank revealed a second mound of solids.

In order to remove the solids from Tank 50H, High Level Waste Operations personnel have installed two additional slurry pumps and plan to add either Tank $23 \mathrm{H}$ supernate or Inhibited Water to reslurry the solids. Addition of these liquids could increase the decomposition rate of the $4 \mathrm{~PB}$ and lead to higher benzene generation rate.

SRTC personnel estimated the maximum 4PB decomposition rate to be $5.0 \mathrm{~mol} / \mathrm{day}+9.6 \mathrm{x}$ $10^{-7} \mathrm{~mol} / \mathrm{L} /$ day $^{1}$. Table 1 below summarizes the benzene generation rate at various tank levels.

\section{Table 1 - Predicted 4PB Decomposition Rate, mol/day}

\begin{tabular}{|c|c|}
\hline $\begin{array}{c}\text { Volume, } \\
\text { gallons }\end{array}$ & $\begin{array}{c}\text { Predicted 4PB } \\
\text { decomposition } \\
\text { rate, mol/day }\end{array}$ \\
\hline $\mathbf{3 0 0 , 0 0 0}$ & $\mathbf{6 . 1}$ \\
\hline 400,000 & 6.5 \\
\hline 600,000 & 7.2 \\
\hline 800,000 & 7.9 \\
\hline $\mathbf{1 , 0 0 0 , 0 0 0}$ & $\mathbf{8 . 6}$ \\
\hline $1,200,000$ & 9.4 \\
\hline $1,400,000$ & 10.1 \\
\hline
\end{tabular}

This task is designed to measure the 4PB decomposition rate for the slurrying of the Tank $50 \mathrm{H}$ solids with Tank $23 \mathrm{H}$ or Inhibited Water solution (Phase 1) and the decomposition rate of any solids left behind after the slurry operation is complete (Phase 2).

\section{$\underline{\text { Experimental }}$}

Two phases of testing were planned ${ }^{2}$ to answer two questions related to two processing decisions.

Phase 1 -- What flammability impact would there be if Tank $23 \mathrm{H}$ supernate or inhibited water was used to reslurry the Tank $50 \mathrm{H}$ solids? Would the addition lead to high benzene generation rates?

Phase 2 -- If some Tank $50 \mathrm{H}$ solids were left behind after attempting to reslurry the Tank $50 \mathrm{H}$ solids, what flammability impact would there be if a high hydroxide or high nitrate (low hydroxide) supernate was transferred into Tank $50 \mathrm{H}$ ? Would the addition lead to high benzene generation rates? 
Actual Tank $50 \mathrm{H}$ solids were used in each of the experiments. A solution (Tank 23 waste, IW, high hydroxide or low hydroxide simulant) was combined with the Tank $50 \mathrm{H}$ solids in a $250 \mathrm{ml}$ polypropylene sample bottle. The bottles were temperature controlled and mixed by placing them in an orbital shaker to simulate the expected Tank $50 \mathrm{H}$ temperature (ambient and $50{ }^{\circ} \mathrm{C}$ ). After the slurry was held at temperature for the desired hold time (one to six weeks), the sample bottle was removed from the orbital shaker and submitted to ADS for analysis. Tom White of ADS extracted the organic from the sample using acetonitrile and analyzed the extracted sample for 4PB degradation products using High Pressure Liquid Chromatography (HPLC). Knowing the extraction efficiency of the solvent, the 4PB degradation products can be accurately estimated. The concentration of $4 \mathrm{~PB}$ in the analysis was used to estimate the $4 \mathrm{~PB}$ degradation rate. The degradation products were used to determine the extent of the degradation and as a secondary method for calculating the degradation rate.

\section{Solids Preparation}

Early testing showed that $4 \mathrm{~PB}$ analyses varied from $60-1150 \mathrm{mg} 4 \mathrm{~PB} / \mathrm{L}_{\text {solids }}{ }^{3}$. The tank $50 \mathrm{H}$ solids were not uniform in composition, so care was taken to homogenize the Tank $50 \mathrm{H}$ solids. The solids were placed in a dish and the solid size was reduced using a pestle and scoopula. The homogenized solids were added to a $500 \mathrm{ml}$ wide mouth polyethylene bottle and were then split into $1.8 \mathrm{~g}$ sub-samples.

\section{Sample Preparation}

Even after the solids were homogenized, 4PB variability within the sub-samples was similar to the variability of the original Tank $50 \mathrm{H}$ solids samples. In order to minimize the impact of sample variability, a decision was made to extract the organic from the whole sample rather than trying to pull a representative sub-sample from the bottle. In order to treat the $1.8 \mathrm{~g}$ solid sample, the entire sample was contacted with acetonitrile to extract the organic species. Analysis of the samples by this method led to minimal sample to sample variation (Table 2). In order to demonstrate that acetonitrile was a reliable method for extracting the organic species of interest, a second extraction with the same sample and no $4 \mathrm{~PB}$ or degradation products were detected.

Based on these analyses, using $95 \%$ confidence limits, the Tank $50 \mathrm{H}$ solids contain $357.7 \pm 8.0 \mathrm{mg} 4 \mathrm{~PB} / \mathrm{kg}$ solids, $<203 \mathrm{~PB} \mathrm{mg} / \mathrm{kg}$ solids, $<20 \mathrm{mg} 2 \mathrm{~PB} / \mathrm{kg}$ solids, $<20$ $\mathrm{mg} 1 \mathrm{~PB} / \mathrm{kg}$ solids and $41.0 \pm 5.0 \mathrm{mg}$ phenol $/ \mathrm{kg}$ solids.

Table 2 - 4PB analysis of 1.8 gram sub-samples, $\mathrm{mg} / \mathrm{kg}$ solids

\begin{tabular}{|l|l|l|l|l|l|}
\hline Sample ID & $\underline{4 P B}$ & $\underline{3 P B}$ & $\underline{2 P B}$ & $\underline{\text { PBA }}$ & $\underline{\text { Phenol }}$ \\
\hline $3-192053$ & 354 & $<20$ & $<20$ & $<20$ & 39 \\
\hline $3-192054$ & 359 & $<20$ & $<20$ & $<20$ & 43 \\
\hline $3-192055$ & 360 & $<20$ & $<20$ & $<20$ & 41 \\
\hline
\end{tabular}


Page 7 of 20

Based on the above Solids composition and the mass of the added solutions, the starting concentration of $4 \mathrm{~PB}$ and degradation products was calculated for the various solutions. The results are reported in Table 3 .

Table 3 - Predicted Starting Composition, mg/kg

\begin{tabular}{|c|c|c|c|c|c|c|c|c|c|c|}
\hline \multirow[b]{2}{*}{ Added Solution } & \multirow{2}{*}{$\begin{array}{l}\text { Solution } \\
\text { Density, } \\
\mathrm{g} / \mathrm{ml}\end{array}$} & \multirow{2}{*}{$\begin{array}{l}\text { Added } \\
\text { Solution } \\
, \mathrm{ml}\end{array}$} & \multirow{2}{*}{$\begin{array}{l}\text { Added } \\
\text { Solution } \\
\text { Mass, g }\end{array}$} & \multirow{2}{*}{$\begin{array}{l}\text { Solids } \\
\text { mass, g }\end{array}$} & \multirow{2}{*}{$\begin{array}{l}\text { Solution } \\
\text { mass, g }\end{array}$} & \multicolumn{5}{|c|}{ Concentration, $\mathrm{mg} / \mathrm{kg}$} \\
\hline & & & & & & $\underline{4 \mathrm{~PB}}$ & $\underline{3 \mathrm{~PB}}$ & $\underline{2 \mathrm{~PB}}$ & $\underline{\mathrm{PBA}}$ & Phenol \\
\hline Tank 23 & 1.005 & 17 & 17.085 & 1.8 & 18.885 & 34.1 & $<2$ & $<2$ & $<2$ & 3.9 \\
\hline Inhibited water & 1 & 17 & 17 & 1.8 & 18.8 & 34.2 & $<2$ & $<2$ & $<2$ & 3.9 \\
\hline Inhibited water & 1 & 5.2 & 5.2 & 1.8 & 7 & 92.0 & $<2$ & $<2$ & $<2$ & 10.5 \\
\hline High Hydroxide & 1.244 & 17 & 21.148 & 1.8 & 22.948 & 28.1 & $<2$ & $<2$ & $<2$ & 3.2 \\
\hline High Nitrate & 1.271 & 17 & 21.607 & 1.8 & 23.407 & 27.5 & $<2$ & $<2$ & $<2$ & 3.2 \\
\hline
\end{tabular}

\section{Phase 1 - Slurry Testing}

Phase 1 testing was designed to measure the tetraphenyl borate decomposition rate and benzene generation rate if the Tank $50 \mathrm{H}$ solids were combined with Tank $23 \mathrm{H}$ supernate (0.27 M free hydroxide) or Inhibited Water (IW, 0.01 M sodium nitrite, $0.01 \mathrm{M}$ sodium hydroxide). HLW personnel will use either Tank $23 \mathrm{H}$ supernate or IW to attempt to reslurry the Tank $50 \mathrm{H}$ solids. Because a limited quantity of Tank $23 \mathrm{H}$ supernate was available, most of the Phase 1 testing was completed with IW. The Phase 1 experiments are summarized in Table 4.

Table 4 -- Phase 1 Experiment Summary Table

\begin{tabular}{|c|c|c|c|c|c|}
\hline Experiment & Temp, ${ }^{\circ} \mathrm{C}$ & Solution & \# Weeks & $\begin{array}{c}\text { Solids } \\
\text { Required, } \\
\text { g }\end{array}$ & $\begin{array}{c}\text { Liquid } \\
\text { Required, } \\
\text { mL }\end{array}$ \\
\hline $\begin{array}{l}\text { Task1 } \\
\text { Experiment } 1\end{array}$ & $50^{\circ} \mathrm{C}$ & $\begin{array}{c}\text { Inhibited } \\
\text { Water }\end{array}$ & 6 & 1.8 & 5.1 \\
\hline $\begin{array}{l}\text { Task1 } \\
\text { Experiment } 2\end{array}$ & Ambient & $\begin{array}{c}\text { Inhibited } \\
\text { Water }\end{array}$ & 2 & 1.8 & 17 \\
\hline $\begin{array}{l}\text { Task1 } \\
\text { Experiment } 3\end{array}$ & $50^{\circ} \mathrm{C}$ & Tank $23 \mathrm{H}$ & 6 & 1.8 & 17 \\
\hline $\begin{array}{l}\text { Task1 } \\
\text { Experiment } 4\end{array}$ & $50^{\circ} \mathrm{C}$ & $\begin{array}{l}\text { Inhibited } \\
\text { Water }\end{array}$ & 6 & 1.8 & 17 \\
\hline
\end{tabular}

The Tank $50 \mathrm{H}$ solids were combined with liquid in a $250 \mathrm{ml}$ polypropylene sample bottle. The samples were capped, placed in a room temperature or $50{ }^{\circ} \mathrm{C}$ orbital shaker, and held at temperature as long as required. The sample bottle was removed and submitted to ADS for analyses. ADS consumed the entire sample by using acetonitrile to extract the organic from 
Page 8 of 20

the sample. The Tank $50 \mathrm{H}$ samples were $357.7 \mathrm{mg} 4 \mathrm{~PB} / \mathrm{kg}$ solids which would give a starting concentration of $\sim 30 \mathrm{mg} 4 \mathrm{~PB} / \mathrm{kg}$ slurry after combining the Tank $50 \mathrm{H}$ solids with $17 \mathrm{ml}$ of solution or $\sim 90 \mathrm{mg} 4 \mathrm{~PB} / \mathrm{kg}$ slurry after combining the Tank $50 \mathrm{H}$ solids with $5.1 \mathrm{ml}$ of solution.

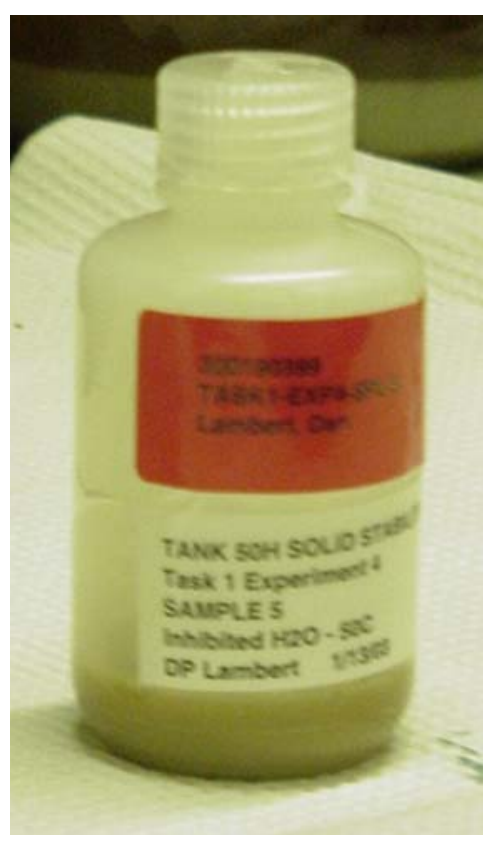

Figure 1 - Photograph of Tank 50H solids plus Inhibited Water

\section{Phase 2 - Solids Left Behind Testing}

If the Tank $50 \mathrm{H}$ solids could not be removed by slurrying and pumping them to Saltstone, would there be any disadvantage to leaving the solids in Tank $50 \mathrm{H}$ and allowing any HLW to be transferred into Tank $50 \mathrm{H}$ ? The Phase 2 experiments are summarized in Table 5.

Table 5 - Phase 2 Experiments Summary Table

\begin{tabular}{|c|c|c|c|c|c|}
\hline Experiment & $\begin{array}{c}\text { Temp, } \\
{ }^{\circ} \mathbf{C}\end{array}$ & Solution & $\begin{array}{c}\# \\
\text { Weeks }\end{array}$ & $\begin{array}{c}\text { Solids } \\
\text { Required, g }\end{array}$ & $\begin{array}{c}\text { Liquid } \\
\text { Required, mL }\end{array}$ \\
\hline Task2 Experiment 1 & Ambient & $\begin{array}{c}\text { High Hydroxide } \\
\text { Simulant }\end{array}$ & 6 & 1.8 & 17 \\
\hline Task2 Experiment 2 & $50^{\circ} \mathrm{C}$ & $\begin{array}{c}\text { High Hydroxide } \\
\text { Simulant }\end{array}$ & 6 & 1.8 & 17 \\
\hline Task2 Experiment 3 & Ambient & $\begin{array}{c}\text { Low Hydroxide } \\
\text { Simulant }\end{array}$ & 6 & 1.8 & 17 \\
\hline
\end{tabular}

Two solutions were chosen to represent the extremes, a high hydroxide simulant and a high nitrate (low hydroxide) simulant. These simulants have been used in a variety of SRS and 
Page 9 of 20

ORNL tests since 1991. ${ }^{4}$ A suite of catalysts, sludge, and MST (Enhanced Catalyst Composition $^{5}$ or ECC) was added to ensure that any metal catalyst that might decompose the $4 \mathrm{~PB}$ would be present in the simulant. The simulants (Table 6) and ECCs (Table 7) are summarized below.

Table 6 - Recipe for High Hydroxide and High Nitrate Simulants

\begin{tabular}{|c|c|c|c|c|c|c|}
\hline \multicolumn{3}{|c|}{ Target $\mathrm{Na}^{+}(\mathrm{M})$} & \multicolumn{2}{|c|}{5.6} & \multicolumn{2}{|c|}{5.6} \\
\hline \multicolumn{3}{|c|}{ Volume required $(\mathrm{L})$ : } & \multicolumn{2}{|c|}{1.00} & \multicolumn{2}{|c|}{1.00} \\
\hline \multicolumn{3}{|l|}{ Simulant } & \multicolumn{2}{|c|}{ High Hydroxide Simulant } & \multicolumn{2}{|c|}{ High Nitrate Simulant } \\
\hline Component & Form & MW & Molarity & Required (g) & Molarity & $\begin{array}{l}\text { Required } \\
\text { (g) }\end{array}$ \\
\hline $\mathrm{NaOH}$ & $\mathrm{NaOH}$ & 40 & 3.05 & 165.52 & 1.17 & 98.40 \\
\hline $\mathrm{NaNO}_{3}$ & $\mathrm{NaNO}_{3}$ & 84.99 & 1.08 & 20.40 & 2.84 & 159.43 \\
\hline $\mathrm{NaNO}_{2}$ & $\mathrm{NaNO}_{2}$ & 69 & 0.740 & 51.06 & 0.370 & 25.53 \\
\hline $\mathrm{NaAlO}_{2}$ & $\mathrm{Al}\left(\mathrm{NO}_{3}\right)_{3} \cdot 9 \mathrm{H}_{2} \mathrm{O}$ & 375.14 & 0.270 & 101.29 & 0.320 & 120.04 \\
\hline $\mathrm{Na}_{2} \mathrm{SO}_{4}$ & $\mathrm{Na}_{2} \mathrm{SO}_{4}$ & 142.04 & 0.0300 & 4.26 & 0.220 & 31.25 \\
\hline $\mathrm{Na}_{2} \mathrm{CO}_{3}$ & $\mathrm{Na}_{2} \mathrm{CO}_{3} \cdot \mathrm{H}_{2} \mathrm{O}$ & 124.01 & 0.170 & 21.08 & 0.160 & 19.84 \\
\hline $\mathrm{NaCl}$ & $\mathrm{NaCl}$ & 58.44 & 0.0100 & 0.563 & 0.0400 & 2.329 \\
\hline $\mathrm{NaF}$ & $\mathrm{NaF}$ & 41.99 & 0.0100 & 0.420 & 0.0500 & 2.100 \\
\hline $\mathrm{Na}_{3} \mathrm{PO}_{4}$ & $\mathrm{Na}_{3} \mathrm{PO}_{4} \cdot 12 \mathrm{H}_{2} \mathrm{O}$ & 380.13 & 0 & 0.000 & 0 & 0.000 \\
\hline $\mathrm{Na}_{2} \mathrm{HPO}_{4}$ & $\mathrm{Na}_{2} \mathrm{HPO}_{4} \cdot 7 \mathrm{H}_{2} \mathrm{O}$ & 268.09 & 0.0080 & 2.145 & 0.0100 & 2.681 \\
\hline $\mathrm{Na}_{2} \mathrm{C}_{2} \mathrm{O}_{4}$ & $\mathrm{Na}_{2} \mathrm{C}_{2} \mathrm{O}_{4}$ & 134 & 0.0080 & 1.072 & 0.0080 & 1.072 \\
\hline $\mathrm{Na}_{2} \mathrm{SiO}_{3}$ & $\mathrm{Na}_{2} \mathrm{SiO}_{3} \cdot 9 \mathrm{H}_{2} \mathrm{O}$ & 284.2 & 0.00400 & 1.137 & 0.00400 & 1.137 \\
\hline $\mathrm{Na}_{2} \mathrm{MoO}_{4}$ & $\mathrm{Na}_{2} \mathrm{MoO}_{4} \cdot 2 \mathrm{H}_{2} \mathrm{O}$ & 241.95 & 0.0002 & 0.0484 & 0.0002 & 0.0484 \\
\hline $\mathrm{KNO}_{3}$ & $\mathrm{KNO}_{3}$ & 101.1 & 0.0300 & 3.0330 & 0.00410 & 0.4145 \\
\hline $\mathrm{CsCl}$ & $\mathrm{CsCl}$ & 168.36 & 0.00037 & 0.0623 & 0.00014 & 0.0236 \\
\hline Water & Water & 18.018 & & 871.8 & & 806.3 \\
\hline
\end{tabular}


Page 10 of 20

Table 7 - Enhanced Catalyst Composition

\begin{tabular}{|c|c|c|}
\hline Component & Compound & $\begin{array}{c}\text { Species Concentration in } \\
\text { Slurry }(\mathrm{mg} / \mathrm{L})\end{array}$ \\
\hline $\mathrm{Pd}$ & $\mathrm{Pd}\left(\mathrm{NO}_{3}\right)_{2}$ & 13.0 \\
\hline $\mathrm{Cu}$ & $\mathrm{Cu}\left(\mathrm{SO}_{4} \cdot 5 \mathrm{H}_{2} \mathrm{O}\right.$ & 3.7 \\
\hline $\mathrm{Hg}$ & $\mathrm{Hg}\left(\mathrm{NO}_{3}\right)_{2} \bullet \mathrm{H}_{2} \mathrm{O}$ & 2.2 \\
\hline diphenylmercury & $\left(\mathrm{C}_{6} \mathrm{H}_{5}\right)_{2} \mathrm{Hg}$ & 150 \\
\hline $\mathrm{Mo} / \mathrm{Cr} / \mathrm{Si} / \mathrm{Se} / \mathrm{As}$ & $\begin{array}{c}\mathrm{Na}_{2} \mathrm{MoO}_{4} \bullet 2 \mathrm{H}_{2} \mathrm{O} \\
\mathrm{Na}_{2} \mathrm{CrO}_{4} \\
\mathrm{Na}_{2} \mathrm{SiO}_{3} \bullet 9 \mathrm{H}_{2} \mathrm{O} \\
\mathrm{Na}_{2} \mathrm{SeO}_{4} \\
\mathrm{As}_{2} \mathrm{O}_{3} \\
\end{array}$ & $\begin{array}{c}12 \\
60 \\
16 \\
1 \\
0.04\end{array}$ \\
\hline $\mathrm{Zn} / \mathrm{Pb} / \mathrm{Fe}$ & $\begin{array}{c}\mathrm{Zn}\left(\mathrm{NO}_{3}\right)_{2} \bullet 4 \mathrm{H}_{2} \mathrm{O} \\
\mathrm{Pb}\left(\mathrm{NO}_{3}\right)_{2} \\
\mathrm{Fe}\left(\mathrm{NO}_{3}\right)_{3} \bullet 9 \mathrm{H}_{2} \mathrm{O}\end{array}$ & $\begin{array}{l}8.8 \\
1.2 \\
2.6 \\
\end{array}$ \\
\hline $\mathrm{Sn}$ & $\mathrm{SnCl}_{2}$ & 2.1 \\
\hline $\mathrm{Ca} / \mathrm{La} / \mathrm{Co}$ & $\begin{array}{c}\mathrm{Ca}\left(\mathrm{NO}_{3}\right)_{2} \bullet 4 \mathrm{H}_{2} \mathrm{O} \\
\mathrm{La}\left(\mathrm{NO}_{3}\right)_{3} \bullet 6 \mathrm{H}_{2} \mathrm{O} \mathrm{Co}\left(\mathrm{NO}_{3}\right)_{2} \bullet 6 \mathrm{H}_{2} \mathrm{O}\end{array}$ & $\begin{array}{l}12.2 \\
0.05 \\
0.04\end{array}$ \\
\hline $\mathrm{Cd} / \mathrm{Ce}$ & $\begin{array}{l}\mathrm{Cd}\left(\mathrm{NO}_{3}\right)_{2} \bullet 4 \mathrm{H}_{2} \mathrm{O} \\
\mathrm{Ce}\left(\mathrm{NO}_{3}\right)_{3} \bullet 6 \mathrm{H}_{2} \mathrm{O}\end{array}$ & $\begin{array}{l}0.4 \\
0.3 \\
\end{array}$ \\
\hline $\mathrm{Rh}$ & $\mathrm{Rh}\left(\mathrm{NO}_{3}\right)_{3}$ & 1.4 \\
\hline $\mathrm{Ag}$ & $\mathrm{AgNO}_{3}$ & 6.8 \\
\hline $\mathrm{Ru}$ & $\mathrm{RuCl}_{3} \bullet \mathrm{xH}_{2} \mathrm{O}$ & 5.4 \\
\hline sludge $^{*}$ & Sludge & 500 \\
\hline $\mathrm{MST}^{\&}$ & MST & 500 \\
\hline
\end{tabular}

* SRTC Purex simulant sludge (IDMS last batch of Purex 01-16-97 without noble metals). ${ }^{\&}$ Monosodium titanate from TNX containing $1 \mathrm{wt} \%$ composite of three 1 Liter bottles dated 01-23-01. Mark Barnes previously used this material for other testing ${ }^{6}$.

Testing was completed as was described in Phase 1. For each test, six sample bottles were prepared by combining $1.8 \mathrm{~g}$ Tank $50 \mathrm{H}$ solids, and $17 \mathrm{ml}$ simulant with noble metals. The sample bottles were placed in a shaker bath and pulled as required for analysis.

\section{$\underline{\text { Results }}$}

\section{Phase 1 - Slurry Testing}

Question 1 - What is the 4PB decomposition rate of Tank 50H solids in Tank 23H and Inhibited Water?

Experiments 3 and 4 were designed to be identical; except that experiment 3 used Tank $23 \mathrm{H}$ supernate and experiment 4 used IW. The data are summarized in Figure $2^{*}$. As can be seen from the data, Tank $23 \mathrm{H}$ leads to faster 4PB decomposition than Inhibited Water. Based on this data, the 4PB decomposition rate is $-2.23 \mathrm{E}-06 \pm 1.33 \mathrm{E}-06 \mathrm{~mol} / \mathrm{L} /$ day for Tank $23 \mathrm{H}$ and $-1.74 \mathrm{E}-06 \pm 0.35 \mathrm{E}-06 \mathrm{~mol} / \mathrm{L} /$ day for $\mathrm{IW}$ at $50{ }^{\circ} \mathrm{C}$, assuming a linear regression analysis based on the calculated initial $4 \mathrm{~PB}$ concentrations. Note at these rates, the 4PB would be destroyed in six to nine weeks.

\footnotetext{
* 0.3 E6 in the Figure 2 refers to experiments simulating the addition of 300,000 gallons of liquid. 1.0 E6 refers to experiments simulating the addition of $1,000,000$ gallons of liquid.
} 


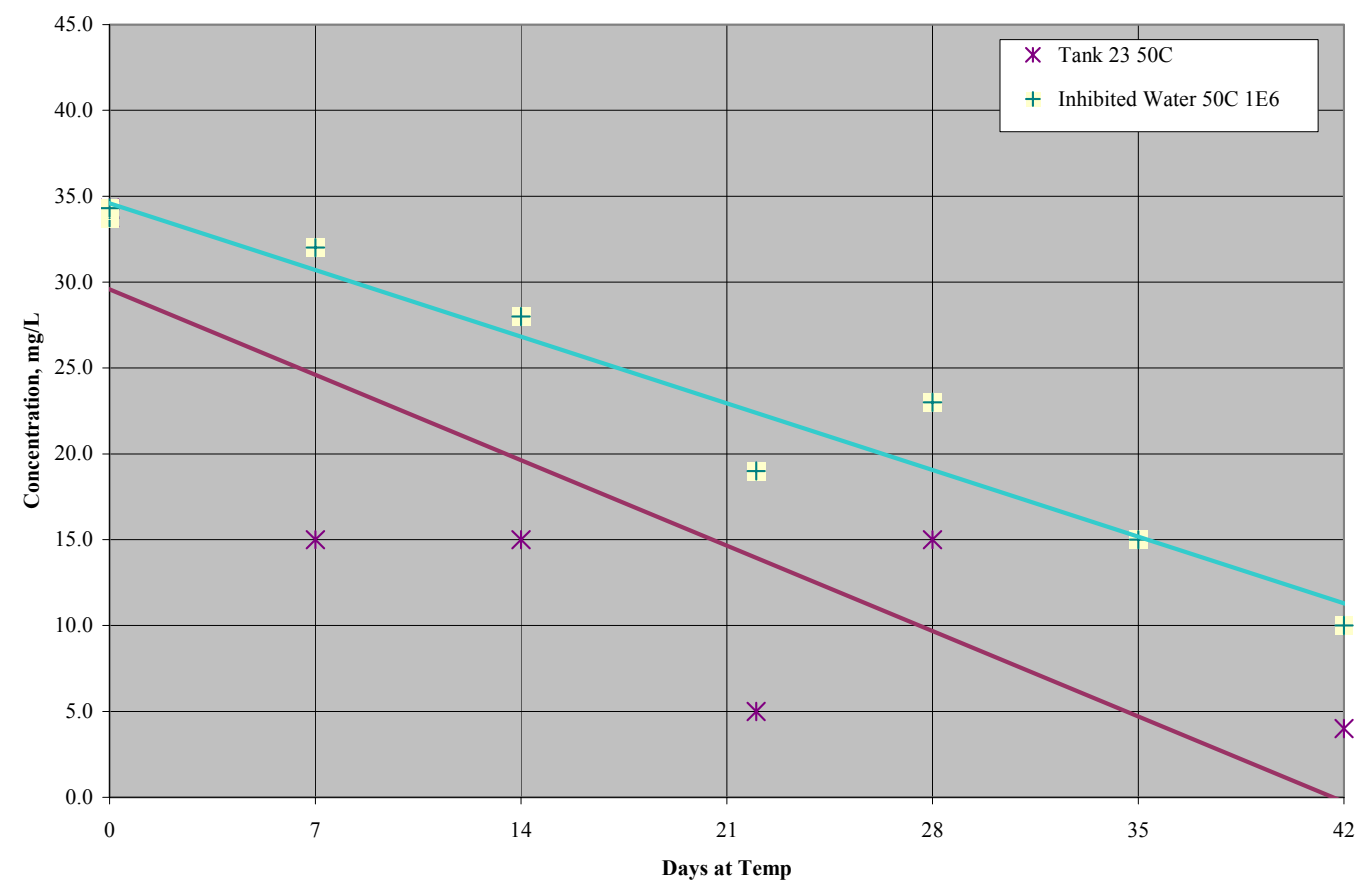

Figure 2 - 4PB Degradation Rate Comparison of IW versus Tank 23H supernate Question 2 - What is the benzene generation rate of Tank $23 \mathrm{H}$ compared to IW?

The maximum benzene generation rate is four times the $4 \mathrm{~PB}$ decomposition rate or $8.90 \mathrm{E}-$ $06 \pm 5.30 \mathrm{E}-06 \mathrm{~mol} / \mathrm{L} /$ day for Tank $23 \mathrm{H}$ and $6.95 \mathrm{E}-06 \pm 1.41 \mathrm{E}-06 \mathrm{~mol} / \mathrm{L} /$ day for $\mathrm{IW}$ at 50 ${ }^{\circ} \mathrm{C}$, assuming a linear regression analysis based on the calculated initial $4 \mathrm{~PB}$ concentrations. $4 \mathrm{~PB}$ can decompose to a variety of products including benzene and phenol. Although the $4 \mathrm{~PB}$ decomposition rate is fast in the experiments at $50{ }^{\circ} \mathrm{C}$, the phenol concentration suggests that the predominant decomposition product is phenol, not benzene. Samples taken at the end of the third week of testing were analyzed for both benzene and phenol using GC/MS. Note there is 10-15 times as much phenol as benzene in these samples. The data from the first three weeks is summarized in Table 8 . Based on this data, the benzene generation rate is $8.90 \mathrm{E}-07 \pm 5.30 \mathrm{E}-07 \mathrm{~mol} / \mathrm{L} /$ day for Tank $23 \mathrm{H}$ and $6.95 \mathrm{E}-07 \pm 1.41 \mathrm{E}-07$ $\mathrm{mol} / \mathrm{L} /$ day for IW at $50{ }^{\circ} \mathrm{C}$.

Table 8 - Data Comparison for Week \#3 Testing comparing IW and Tank $23 \mathrm{H}$ at 50 ${ }^{\circ} \mathbf{C}$

\begin{tabular}{|c|c|c|c|c|c|r|r|}
\hline & \multicolumn{5}{|c|}{ HPLC, mg/L } & \multicolumn{2}{c|}{ SVOA, mg/L } \\
\hline $\begin{array}{c}\text { Experiment / } \\
\text { Analyte } \rightarrow\end{array}$ & $\underline{4 \mathrm{~PB}}$ & $\underline{3 \mathrm{~PB}}$ & $\underline{2 \mathrm{~PB}}$ & $\underline{\text { PBA }}$ & $\underline{\underline{\text { Phenol }}}$ & $\underline{\underline{\text { Phenol }}}$ & $\underline{\text { Benzene }}$ \\
\hline Tank 50 & 5 & $<1$ & $<1$ & 6 & 26 & 24 & 2.5 \\
\hline Inhibited Water & 19 & $<1$ & $<1$ & 6 & 18 & 27 & 1.8 \\
\hline
\end{tabular}


Note also that the destruction rate of 4PB is nearly equal to the phenol generation rate, suggesting that the primary decomposition product is phenol, not benzene. The data is summarized in Figure 3.

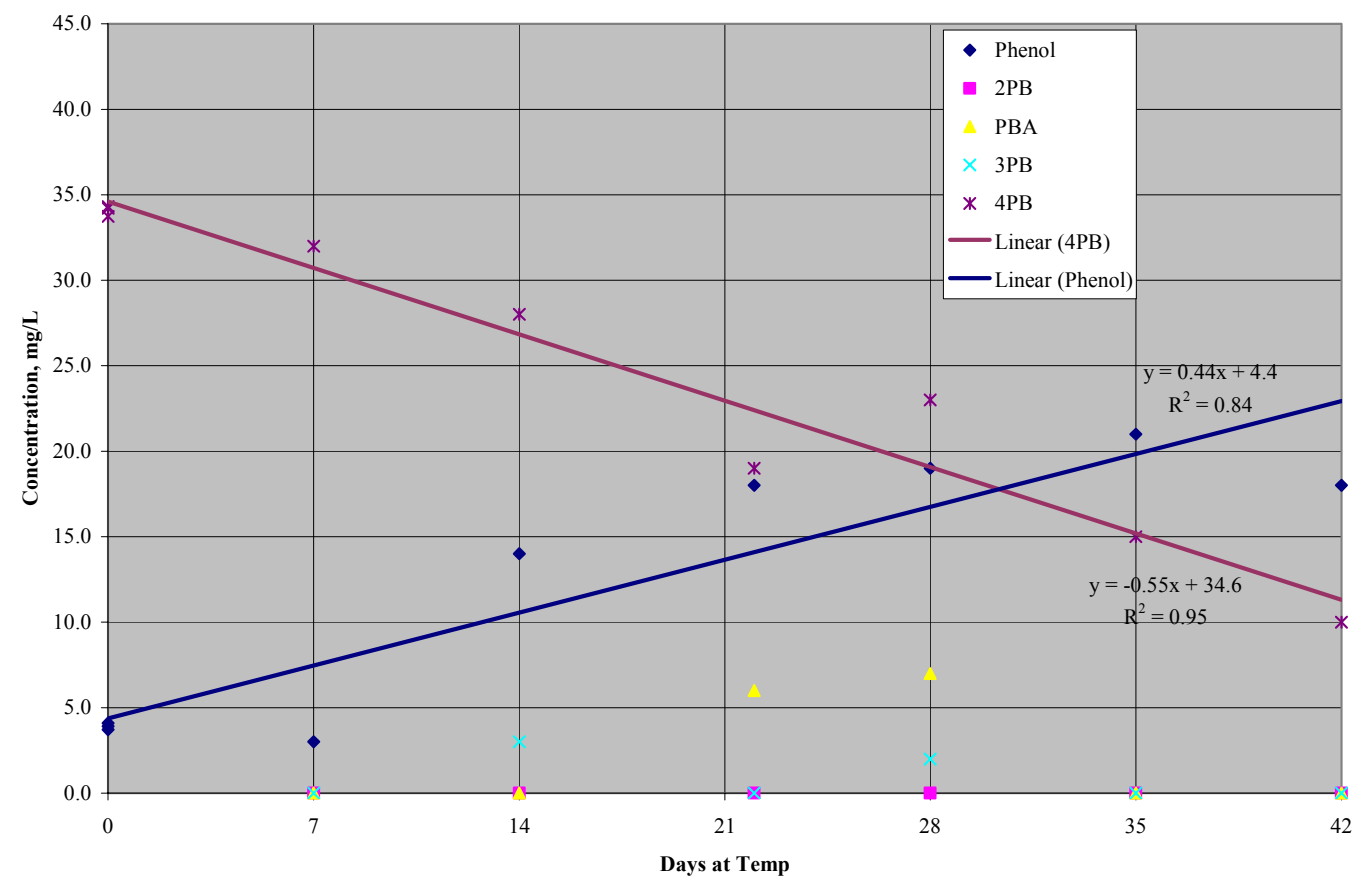

Figure 3 - Phenol and 4PB concentration profiles for IW plus Tank 50H solids at $50{ }^{\circ} \mathrm{C}$

\section{Question 3 - What is the 4PB decomposition rate with 300,000 gallons of IW versus $1,000,000$ gallons of IW?}

Experiments 1 and 4 were designed to be identical; except that experiment 2 added $5.1 \mathrm{ml}$ of inhibited water to $1.8 \mathrm{~g}$ Tank $50 \mathrm{H}$ solids to simulate the addition of 300,000 gallons of IW to Tank $50 \mathrm{H}$. Experiment 2 added $17 \mathrm{ml}$ of inhibited water to $1.8 \mathrm{~g}$ Tank $50 \mathrm{H}$ solids to simulate the addition of 1,000,000 gallons of IW to Tank 50H. Both experiments were performed at $50^{\circ} \mathrm{C}$.

To simplify the comparison of the two experiments, the data at 300,000 gallons were corrected by dilution as if 1,000,000 gallons were present. The data is summarized in Table 9. The 4PB decomposition rate is SUMMARY OUTPUT

Regression Statistics

Multiple R $\quad 0.508760994$

R Square $\quad 0.258837749$

Adjusted R Square

$-9.86 \mathrm{E}-07$
0.166192468

5.72E-07
Ave Min Max +/-

Rate, mol/day $-1.57 \quad 0.60 \quad-3.73 \quad 2.16$

Rate, $\mathrm{mol} / \mathrm{L} / \mathrm{day} \quad-4.14 \mathrm{E}-07$

1.57E-07 
Standard Error3.606418393

3.94E-06 2.29E-06

Observations 10

$$
\text { Benzene, mol/L/day }-1.66 \mathrm{E}-06
$$

$19 \%$

$6.29 \mathrm{E}-07-$

ANOVA

df $\quad$ SS MS F $\quad$ Significance F

$\begin{array}{lllllll}\text { Regression } & 1 & 36.33762415 & 36.33762415 & 2.793857878 & 0.133169563\end{array}$

$\begin{array}{llll}\text { Residual } & 8 & 104.050029 & 13.00625362\end{array}$

Total $9 \quad 140.3876531$

Coefficients Standard Errort Stat P-value $\quad$ Lower 95\% Upper 95\%

Lower $95.0 \%$ Upper $95.0 \%$

$\begin{array}{llllll}\text { Intercept } & 36.64897268 & 1.751431599 & 20.92515214 & 2.85468 \mathrm{E}-08 & 32.61016156\end{array}$ $40.6877838 \quad 32.61016156 \quad 40.6877838$

X Variable $1 \quad-0.1322504920 .079121615 \quad-1.6714837360 .133169563 \quad-0.31470538$

$0.050204396 \quad-0.31470538 \quad 0.050204396$

0

$277.1178554 \quad 39.58826505$

$\begin{array}{llllll}0 & 33.7 & <2 & <2 & <2 & 3.7 \\ 0 & 34.2 & <2 & <2 & <2 & 4.1 \\ 0 & 34.3 & <2 & <2 & <2 & 3.9 \\ 7 & 37 & <1 & <1 & <2 & 13\end{array}$

II

Task 2

Experiment 2

$\begin{array}{lllllllll} & \text { " 3-190648 } & \text { High Hydroxide } & 17 & 50 & 14 & 41 & <1 & <1\end{array}$

14

$\begin{array}{lllllllll}0 & 3-190651 & \text { High Hydroxide } & 17 & 50 & 21 & 36 & <1 & <5\end{array}$

13

$\begin{array}{lllllllll}0 & 3-190651 & \text { High Hydroxide } & 17 & 50 & 21 & 36 & <1 & <5\end{array}$

13

$\begin{array}{lllllllll}0 & 3-190652 & \text { High Hydroxide } & 17 & 50 & 28 & 36 & <1 & <1\end{array}$

13

$\begin{array}{lllllllll}0 & 3-190653 & \text { High Hydroxide } & 17 & 50 & 35 & 28 & <2 & <2\end{array}$

15

$\begin{array}{lllllllll}0 & 3-190654 & \text { High Hydroxide } & 17 & 50 & 42 & 28 & <1 & <1\end{array}$

$17 \pm 1.33 \mathrm{~mol} /$ day at 300,000 gallons and

$-6.58 \pm 1.33 \mathrm{~mol} /$ day at $1,000,000$ gallons. The higher decomposition rate at the higher volume is likely due to (1) faster dissolution of the Tank $50 \mathrm{H}$ solids since more solution is present and (2) the Tank $23 \mathrm{H}$ solution likely contains catalysts that increase the 4PB 
Page 14 of 20

decomposition and more solution would add more catalyst to the solids. The decomposition rate is $34 \%$ higher at the higher volume.

Table 9 - Comparison of decomposition rate of 300,000 gal versus 1,000,000 gal

\begin{tabular}{|c|c|c|c|c|c|c|}
\hline & $\underline{T}$ Time, days & $\underline{4 P B}$ & $\underline{3 P B}$ & $\underline{2 P B}$ & $\underline{1 P B}$ & $\underline{\text { Phenol }}$ \\
\hline \multirow{3}{*}{$\begin{array}{c}\text { Inhibited Water } \\
50{ }^{\circ} \mathrm{C} \\
300,000 \text { gallons } \\
\text { corrected }\end{array}$} & 7 & 29.1 & 0.90 & - & - & 0.9 \\
\cline { 2 - 7 } & 14 & 32.7 & 1.50 & 1.50 & 2.10 & 9.9 \\
\cline { 2 - 7 } & 28 & 22.8 & 1.50 & - & 3.00 & 14.7 \\
\hline \multirow{3}{*}{$\begin{array}{c}\text { Inhibited Water } \\
50{ }^{\circ} \mathrm{C}\end{array}$} \\
\cline { 2 - 7 } & 35 & 20.7 & 1.50 & - & 2.10 & 15.9 \\
\cline { 2 - 7 } & 42 & 15.6 & 1.50 & - & - & 16.5 \\
\cline { 2 - 7 } gallons & 7 & 32 & $<1$ & $<1$ & $<2$ & 3 \\
\cline { 2 - 7 } & 14 & 28 & 3 & $<1$ & $<2$ & 14 \\
\cline { 2 - 7 } & 22 & 19 & $<1$ & $<1$ & 6 & 18 \\
\hline
\end{tabular}

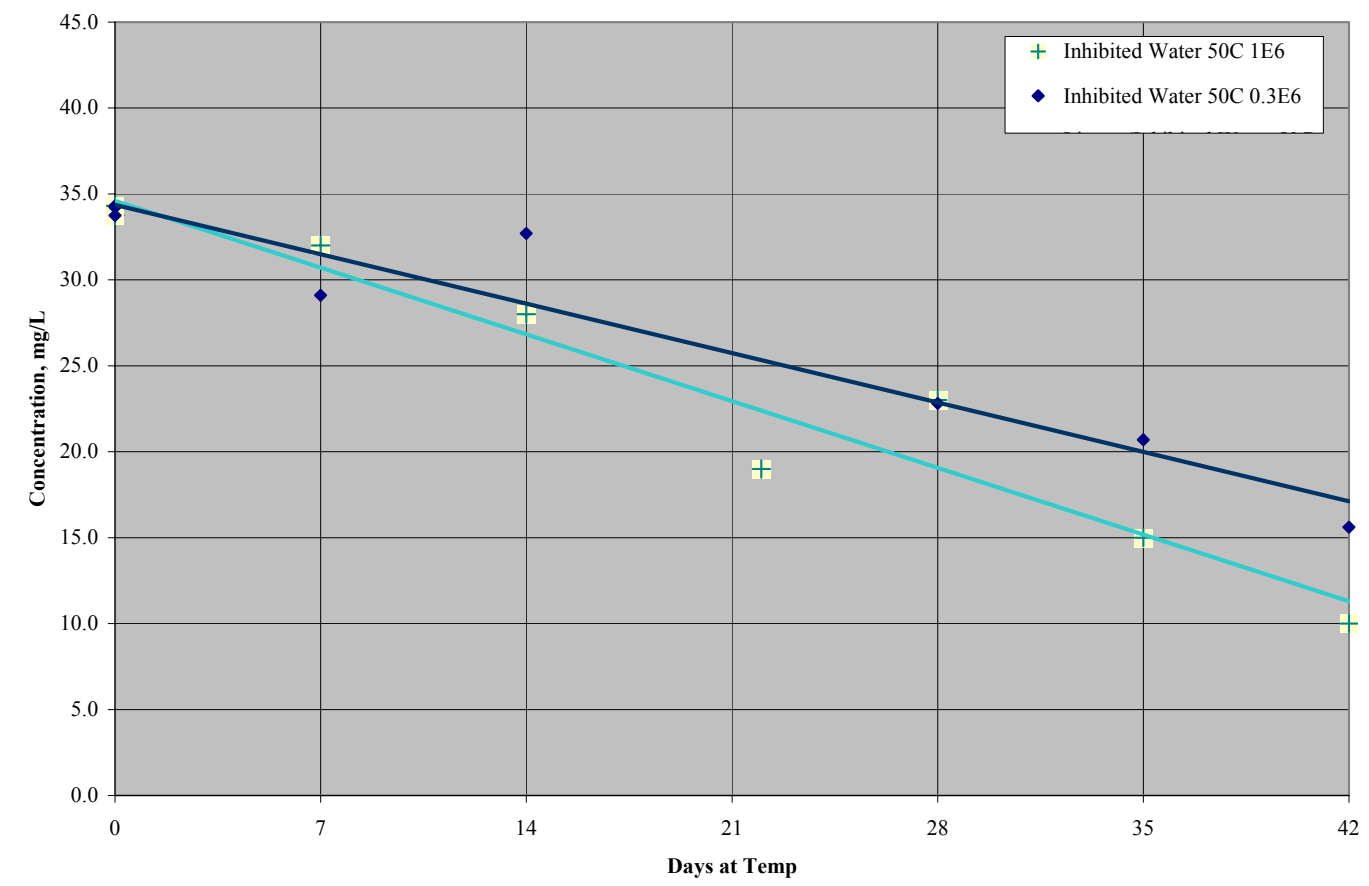

Figure 4 - Comparison of Decomposition Rate at Low versus High Tank Volume

\section{Phase 2 - Solids Left Behind Testing}

Phase 2 was designed to determine the 4PB decomposition rate if the Tank 50 solids remain in Tank $50 \mathrm{H}$ but the tank is returned to routine HLW service. Tank $50 \mathrm{H}$ supplies feed to the Saltstone Facility. A typical feed to Saltstone will be $\sim 5 \mathrm{M}$ sodium, but could range from a 
high nitrate to a high hydroxide composition. As a result two simulant solutions were chosen to represent the extremes, a high hydroxide simulant and a high nitrate (low hydroxide) simulant. A suite of catalysts (sludge, MST and ECCs) was added to ensure that any metal catalyst that might decompose the $4 \mathrm{~PB}$ would be present in the simulant.

\section{Question 4 - What is the 4PB decomposition rate if the solids are left behind in Tank 50H?}

Three sets of experiments were completed in Phase 2. Experiment 1 added the equivalent of $1,000,000$ gallons of high hydroxide simulant (3.05 $\mathrm{M}$ free hydroxide) to 61,000 gallons of solids and was completed over six weeks at ambient temperature. Experiment 2 was identical at $50{ }^{\circ} \mathrm{C}$. Experiment 3 added the equivalent of 1,000,000 gallons of high nitrate simulant (1.17 M free hydroxide) to 61,000 gallons of solids and was completed over six weeks at ambient temperature.

The decomposition of 4PB was significantly lower in the Phase 2 Experiments. The data are summarized in Figure 5 . Based on this data, the 4PB decomposition rate is $-4.14 \mathrm{E}-07 \pm$ $5.72 \mathrm{E}-07 \mathrm{~mol} / \mathrm{L} /$ day for the high hydroxide simulant at $50{ }^{\circ} \mathrm{C}$, assuming a linear regression analysis based on the calculated initial $4 \mathrm{~PB}$ concentrations. Note at these rates, the $4 \mathrm{~PB}$ would be destroyed in approximately 40 weeks. Note the degradation rate in this experiment is approximately $1 / 5^{\text {th }}$ degradation in the Tank 23 experiment.

A 4PB decomposition rate could not be calculated for the two Phase 2 tests at ambient temperature because of the slow decomposition rates. A least squares fit of the data for each experiment calculated a slope of approximately 0 (no degradation). 


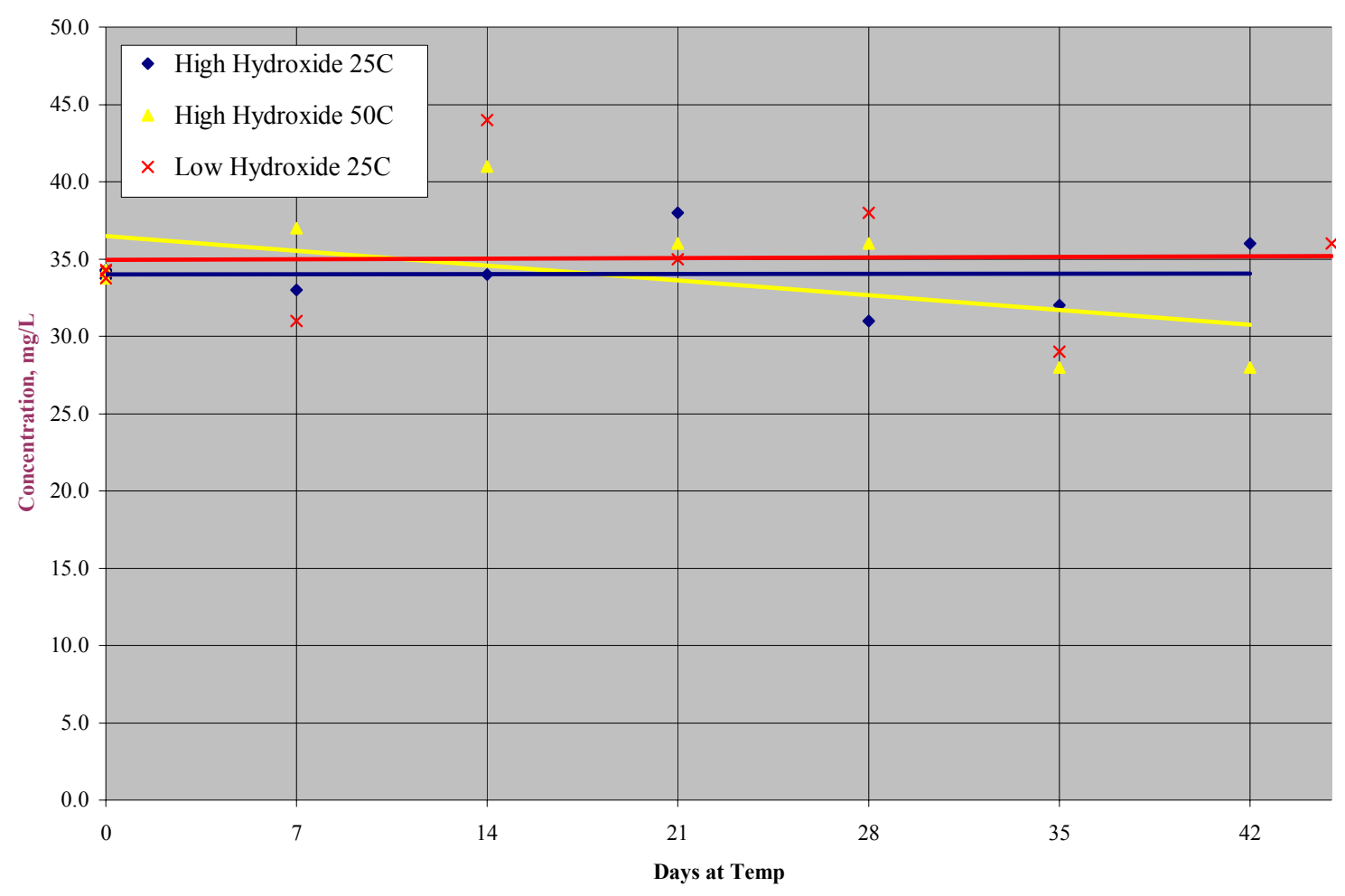

Figure 5 - 4PB decomposition in solids left behind after slurrying

\section{Question 5 - What is the 4PB decomposition rate at $25^{\circ} \mathrm{C}$ compared to $50{ }^{\circ} \mathrm{C}$ ?}

Phase 1 experiments 2 and 4 were designed to be identical; except that experiment 2 used IW at $25^{\circ} \mathrm{C}$ and experiment 4 used IW at $50{ }^{\circ} \mathrm{C}$. Based on the limited information, there is no way to answer this question based on the Phase 1 data (we only have two weeks of data at $25^{\circ} \mathrm{C}$ and one of the two $4 \mathrm{~PB}$ values is $60 \mathrm{mg} / \mathrm{L}$, much higher than the starting concentration). The phase 2 data from experiments 1 and 2 can be used to answer this question, although it can not be quantified. Based on the data in Figure 5, the 4PB is decomposition rate appears higher at $50{ }^{\circ} \mathrm{C}$. The fastest $4 \mathrm{~PB}$ decomposition is expected in solutions that increase the KTPB solubility (lower free hydroxide concentration), that are well mixed, and that are at higher temperatures.

\section{Conclusions}

The 4PB in the Tank $50 \mathrm{H}$ solids decomposed rapidly during testing with Tank $23 \mathrm{H}$ and Inhibited Water solutions at $50{ }^{\circ} \mathrm{C}$. It is expected that the $4 \mathrm{~PB}$ will decompose rapidly in Tank $50 \mathrm{H}$ if the liquid temperature approaches $50{ }^{\circ} \mathrm{C}$ during the planned operation to slurry the Tank $50 \mathrm{H}$ solids and feed the resultant solution to Saltstone. During these evolutions, most of the $4 \mathrm{~PB}$ is expected to decompose. The following are the conclusions from this testing.

This report summarizes the results of testing to determine the 4PB degradation rate of solids in Tank $50 \mathrm{H}$. Phase 1 was designed to determine the tetraphenylborate (4PB) 
decomposition rate of the 4PB present in Tank $50 \mathrm{H}$ if Tank $23 \mathrm{H}$ or Inhibited Water (IW, water with added sodium nitrite and sodium hydroxide to inhibit corrosion of the carbon steel waste tanks) is added to the tank. The following preliminary results, at $95 \%$ confidence limits, are presented:

$>$ The $4 \mathrm{~PB}$ decomposition rate at $50{ }^{\circ} \mathrm{C}$ is $-2.23 \mathrm{E}-06 \pm 1.33 \mathrm{E}-06 \mathrm{~mol} / \mathrm{L} /$ day for Tank $23 \mathrm{H}$ and $-1.74 \mathrm{E}-06 \pm 0.35 \mathrm{E}-06 \mathrm{~mol} / \mathrm{L} /$ day for $\mathrm{IW}$ at $50{ }^{\circ} \mathrm{C}$, assuming a linear regression analysis based on the calculated initial $4 \mathrm{~PB}$ concentrations.

$>$ The maximum benzene generation rate from $4 \mathrm{~PB}$ decomposition is $8.90 \mathrm{E}-06 \pm 5.30 \mathrm{E}-06$ $\mathrm{mol} / \mathrm{L} /$ day for Tank $23 \mathrm{H}$ and $6.95 \mathrm{E}-06 \pm 1.41 \mathrm{E}-06 \mathrm{~mol} / \mathrm{L} /$ day for $\mathrm{IW}$ at $50{ }^{\circ} \mathrm{C}$. This assumes all of the 4PB degrades to benzene.

$>$ Based on our testing, approximately $90 \%$ of the 4 PB primarily decomposes to phenol, not benzene. The likely benzene generation rate from $4 \mathrm{~PB}$ decomposition is roughly $8.90 \mathrm{E}-07 \pm 5.30 \mathrm{E}-07 \mathrm{~mol} / \mathrm{L} /$ day for Tank $23 \mathrm{H}$ and $6.95 \mathrm{E}-07 \pm 1.41 \mathrm{E}-07 \mathrm{~mol} / \mathrm{L} /$ day for IW at $50{ }^{\circ} \mathrm{C}$.

$>$ Because of the limited data available and questions concerning the uniformity of the solids, the $95 \%$ confidence limit that gives the most conservative estimate of the $4 \mathrm{~PB}$ decomposition rate.

$>$ No testing at $100{ }^{\circ} \mathrm{C}$ was performed because of the fast decomposition at $50{ }^{\circ} \mathrm{C}$.

Phase 2 was designed to determine the 4PB decomposition rate if a high hydroxide or high nitrate salt solution is added to the tank. Any $4 \mathrm{~PB}$ solids left behind after the slurry operation are expected to decompose more slowly based on the fact that future solutions are expected to have high free hydroxide concentrations and the tank will be at temperatures closer to ambient than $50{ }^{\circ} \mathrm{C}$.

$>$ The $4 \mathrm{~PB}$ decomposition rate at $50^{\circ} \mathrm{C}$ is $-4.14 \mathrm{E}-07 \pm 5.72 \mathrm{E}-07 \mathrm{~mol} / \mathrm{L} /$ day for High Hydroxide simulants at $50{ }^{\circ} \mathrm{C}$, assuming a linear regression analysis based on the calculated initial $4 \mathrm{~PB}$ concentrations.

The 4PB decomposition is expected to produce primarily phenol, not benzene, during the planned slurrying and feeding of the slurry to Saltstone. Pulling a Tank $50 \mathrm{H}$ slurry sample towards the end of feeding to Saltstone is recommended. The 4PB analysis of this sample could be used to better estimate the $4 \mathrm{~PB}$ potential in Tank $50 \mathrm{H}$ than a solids estimate combined with analyses of Tank $50 \mathrm{H}$ solids after Tank $50 \mathrm{H}$ is emptied. This data could be used to formulate a better flammability strategy for Tank $50 \mathrm{H}$.

$>$ The $4 \mathrm{~PB}$ decomposition rate at $50{ }^{\circ} \mathrm{C}$ is $-2.23 \mathrm{E}-06 \pm 1.33 \mathrm{E}-06 \mathrm{~mol} / \mathrm{L} / \mathrm{day}$ for Tank $23 \mathrm{H}$ and $-1.74 \mathrm{E}-06 \pm 0.35 \mathrm{E}-06 \mathrm{~mol} / \mathrm{L} /$ day for $\mathrm{IW}$ at $50{ }^{\circ} \mathrm{C}$, assuming a linear regression analysis based on the calculated initial $4 \mathrm{~PB}$ concentrations.

$>$ The maximum benzene generation rate from 4PB decomposition is $8.90 \mathrm{E}-06 \pm 5.30 \mathrm{E}-06$ $\mathrm{mol} / \mathrm{L} /$ day for Tank $23 \mathrm{H}$ and $6.95 \mathrm{E}-06 \pm 1.41 \mathrm{E}-06 \mathrm{~mol} / \mathrm{L} /$ day for $\mathrm{IW}$ at $50{ }^{\circ} \mathrm{C}$. This assumes all of the $4 \mathrm{~PB}$ degrades to benzene.

$>$ Based on our testing, approximately $90 \%$ of the 4 PB primarily decomposes to phenol, not benzene. The likely benzene generation rate from $4 \mathrm{~PB}$ decomposition is roughly 
$8.90 \mathrm{E}-07 \pm 5.30 \mathrm{E}-07 \mathrm{~mol} / \mathrm{L} /$ day for Tank $23 \mathrm{H}$ and $6.95 \mathrm{E}-07 \pm 1.41 \mathrm{E}-07 \mathrm{~mol} / \mathrm{L} /$ day for IW at $50{ }^{\circ} \mathrm{C}$.

$>$ Because of the limited data available and questions concerning the uniformity of the solids, the $95 \%$ confidence limit that gives the most conservative estimate of the 4PB decomposition rate.

$>$ No testing at $100{ }^{\circ} \mathrm{C}$ was performed because of the fast decomposition at $50{ }^{\circ} \mathrm{C}$. Phase 2 was designed to determine the $4 \mathrm{~PB}$ decomposition rate if a high hydroxide or high nitrate salt solution is added to the tank. Any 4PB solids left behind after the slurry operation are expected to decompose more slowly based on the fact that future solutions are expected to have high free hydroxide concentrations and the tank will be at temperatures closer to ambient than $50{ }^{\circ} \mathrm{C}$.

$\varnothing \quad$ The $4 \mathrm{~PB}$ decomposition rate at $50{ }^{\circ} \mathrm{C}$ is $-4.14 \mathrm{E}-07 \pm 5.72 \mathrm{E}-07 \mathrm{~mol} / \mathrm{L} /$ day for High Hydroxide simulants at $50{ }^{\circ} \mathrm{C}$, assuming a linear regression analysis based on the calculated initial $4 \mathrm{~PB}$ concentrations.

The 4PB decomposition is expected to produce primarily phenol, not benzene, during the planned slurrying and feeding of the slurry to Saltstone. Pulling a Tank $50 \mathrm{H}$ slurry sample towards the end of feeding to Saltstone is recommended. The 4PB analysis of this sample could be used to better estimate the 4PB potential in Tank $50 \mathrm{H}$ than a solids estimate combined with analyses of Tank $50 \mathrm{H}$ solids after Tank $50 \mathrm{H}$ is emptied. This data could be used to formulate a better flammability strategy for Tank 50H.Acknowledgements

The authors wish to thank Bill Wilmarth, Sam Fink and Tom Peters for their suggestions for designing the experiments and to Bill Wilmarth for supplying the Tank $50 \mathrm{H}$ solids. Also, thanks to Chris Martino for his perseverance in initiating testing to measure the 4PB decomposition rate and to Rob Swingle for providing information concerning the composition of the Tank $23 \mathrm{H}$ solution.

The 4PB and degradation product concentrations were measured by Tom White and Diane Scott of SRTC/ADS. Their planning allowed for quick extraction and rapid turnaround, which was greatly appreciated.

A number of WPT researchers and technicians supported this task including Mark Barnes, Doug Walker, and Vicki Dukes who offered support as requested throughout this task. 
This page intentionally left blank 


\section{$\underline{\text { References }}$}

${ }^{1}$ C. J. Martino, "TPB Decomposition Rate during Slurrying of Solids in Tank 50H” SRT-LWP-2003-00019, Rev. 0, February 4, 2003.

2 D. P. Lambert, “Task Technical and Quality Assurance Plan for Testing to Determine Tank 50H Solids Stability and Flammability Impacts", WSRC-RP-2002-00639, Rev. 0, January 8, 2003.

3 W. R. Wilmarth, Initial Briefing of Tank 50 Solids, SRT-LWP-2002-00115, October 30, 2002.

${ }^{4}$ D. D. Walker and C. J. Coleman, "Densities and Weight \% Solids of Simulated Salt Solutions", WSRC-TR91-176, April 17, 1991.

5 W. R. Wilmarth and C. L. Crawford, "The Influence of High Temperature and Radiation on Inhibiting Agents for the Decomposition of Sodium Tetraphenylborate", WSRC-TR-98-00232, Rev 0, August 3, 1998.

6 T. B. Peters, M. J. Barnes, F. F. Fondeur, S. D. Fink, R. W. Blessing, R. E. Norcia, J. G. Firth, C. W. Kennell, T.R Tipton, and B. B. Anderson, "Demonstration of Small Tank Tetraphenylborate Precipitation Process using Savannah River Site High Level Waste”, WSRC-TR-2001-00211, page 11, May 31, 2001. 